\title{
保育器内の低出生体重児の赤血球輸血に及ぼす放射線照射と 白血球除去フィルター併用の影響
}

\author{
澤 文博122) 岩下 洋一1) 茂木さおり \\ 中島 智子 ${ }^{1)}$ 澤井 清 ${ }^{2)}$ 沢田 健 ${ }^{2)}$ \\ 1) 東邦大学医学部付属佐倉病院輸血部 \\ 2) 東邦大学医学部佐倉病院小览科
}

(平成 10 年 9 月 7 日受付)

(平成 11 年 1 月 5 日受理)

\section{EFFECT OF IRRADIATION AND LEUKOCYTE FILTRATION ON RED CELL TRANSFUSION FOR PREMATURE INFANTS IN AN INCUBATOR}

\author{
Fumihiro Sawa $^{1)}$, Yoichi Iwasita ${ }^{1)}$, Saori Motegi ${ }^{1)}$, Tomoko Nakajima ${ }^{1)}$, \\ Kiyoshi Sawai ${ }^{2)}$ and Ken Sawada ${ }^{2)}$ \\ ${ }^{1)}$ Department of Blood Transfusion, Sakura Hospital, School of Medicine, Toho University \\ ${ }^{2)}$ Department of Pediatrics, Sakura Hospital, School of Medicine, Toho University
}

We investigated the effect of irradiation and leukocyte filtration on red cells in MAP solution (RC-MAP) for premature infants.

RC-MAPs were stored for 3 or 7 days and pretreated with 15-Gy irradiation and a leukocyte depletion filter, with either the irradiation or filtration performed first. Infusion was performed using an infusion pump for $8 \mathrm{hr}$ at a speed of $2 \mathrm{ml} / \mathrm{hr}$ through a $4-\mathrm{ml}, 100-\mathrm{cm}$ tube and a $24 \mathrm{G}$ needle passing into an infant incubator warmed to $34^{\circ} \mathrm{C}$.

Free hemoglobin concentration in the supernatant of tested RC-MAP stored 7 days and irradiated after filtration was increased to the maximum level of $42.6 \mathrm{mg} / \mathrm{d} l$.

Potassium ion level in the supernatants and ATP and 2,3-DPG concentration in red cells from tested RC-MAP were similar to pretreated values. Maximum potassium ion level was increased to $23.5 \mathrm{mEq} / l$.

Our results showed that both irradiation and filtration against RC-MAP solutions stored for 3 or 7 days is safe for use with premature infants in warmed incubators. However, further investigation is necessary to clarify the risk of bacterial contamination in such transfusion situations.

Key words : blood irradiation, leukocyte depletion filter, infant incubator, premature infant

\section{はじめに}

低出生体重児の輸血は成人と異なり, 輸注ポン プを使い，保育器内で細いラインと針を使用して 行われる.さらに最近は輸血後の移植片対宿主病 予防目的に放射線照射 ${ }^{1)}$ や,サイトメガロウイルス 感染予防目的に白血球除去フィルター処理 ${ }^{2}$ が勧 められている。しかし，放射線照射とフィルター
処理を併用して保育器内で輸血操作を行った場合 の安全性を調べた報告は無く，今回報告する.

\section{対象と方法}

試料は千葉県赤十字血液センターから提供され た検査落ちの赤血球 MAP「日赤」 2 単位製剤 $(\mathrm{RC}$ MAP）である． 3 日と 7 日保存の血液を 5 つに分 け，日立メディコ社 MBR-1520 A-2 X 線照射装置 
で $15 \mathrm{~Gy}$ 照射 (照射), アサヒメディカル社 SEPACELL-RS 200 A 白血球除去フィルター処理 (フィルター処理), 照射後フィルター処理, フィ ルター処理後照射の 4 種類の前処理を行い, 残り の $1 つ($ 照射もフィルター処理もしない) を対照 とした。照射に平均 7 分, フィルター処理に平均 10 分 (使用説明書記載の $30 \mathrm{ml} / \mathrm{min}$ で処理) 要し た. その後, 後記の輸血操作を行い開始前, 2 時間 後, 4 時間後, 6 時間後, 8 時間後に血液を採取し, 赤血球内の adenosine triphosphate (ATP) と 2,3diphosphoglycerate (2,3-DPG) の濃度, 上清の遊 離へモグロビンとカリウム・イオン $\left(\mathrm{K}^{+}\right)$濃度を 測定した。

ATP と 2,3-DPG の濃度は Böehringer Mannheim 社のキット ${ }^{344}$ で, 遊離へモグロビン濃度は和光 純薬工業株式会社へモグロビンテストワコー ${ }^{5)}$ で, $\mathrm{K}^{+}$濃度は日立自動分析装置 7150 (電極法) で測定 した.

輸血操作は体重 $1,000 \mathrm{~g}$ の低出生体重児を想定 し, 当院新生児室で行なわれている方法で行った。 すなわち, TERUMO 社テルモシリンジ $20 \mathrm{ml}$ に 前処理後の RC-MAP $20 \mathrm{ml}$ を取り, TOP 社トッ プエクステンションチューブ X 2-100（長さ 100 $\mathrm{cm}$, 容量 $4 \mathrm{ml}$ ）を接続し, その先に TERUMO 社 $24 \mathrm{G} \mathrm{3} / 4$ サーフロー留置針（内径 $0.47 \mathrm{~mm}$, 長 さ $19 \mathrm{~mm})$ を付け, TERUMO 社テルフュージョ ンシリンジポンプ MODEL STC-525にセットし た. ポンプを器内温度 $34^{\circ} \mathrm{C}$, 湿度 $75 \%$ に設定した ATOM 社 INFANT INCUBATOR V-850 保育器 の上に置き, チューブを器内に引き込み, $2 \mathrm{ml} / \mathrm{hr}$ のスピードで注入を行い, 留置針の先端から流出 した血液のうち $2 \mathrm{ml}$ を検体とした. なお, 保育器 内にはチューブが約 $50 \mathrm{~cm}$ 入っており，約 1 時間 保育器内で加温されることになる.

測定值は各検体を 3 回測定した中央值を採用し た. 5 つの処理群それぞれ 5 製品について各測定 ポイント, ならびに各処理群の輸血操作前と 8 時 間輸血操作後の差（変化量）の平均值と標準偏差 を求めた. 輸血操作前值と変化量は $\mathrm{t}$ 検定を行い, 危険率 $5 \%$ 以下で対照と差のあるものを有意とし た.

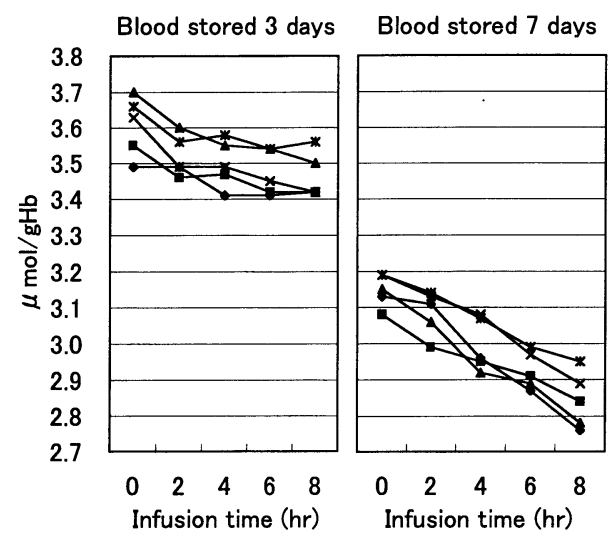

Fig. 1 ATP activity in infused red cells stored 3 or 7 days. Control, $-\bullet-$; Filtration, $-\mathbf{\square}-$; Irradiation, - $-\mathbf{-}$; Filtration after Irradiation, $-\times-$; Irradiation after Filtration, $-*-$ No significant difference versus control.

\section{結 果}

1. MAP 赤血球内 ATP 濃度（Fig. 1)

1）3 日保存血液

輸血操作前值はフィルター処理単独 $(\mathrm{F})$ が 3.55 $\pm 0.36 \mu \mathrm{mol} / \mathrm{gHb}(\mathrm{n}=5)$ (以下単位と $\mathrm{n}$ 数は同じ), 照射単独 (R) が $3.70 \pm 0.39$, 照射後フィルター処理 (RF) が $3.63 \pm 0.46$, フィルター処理後照射 (FR) が $3.66 \pm 0.36$ で, いずれも対照の $3.49 \pm 0.47$ と有意差 がなかった。

変化量は F が $0.14 \pm 0.07 \mu \mathrm{mol} / \mathrm{gHb} / 8 \mathrm{~h} \quad(\mathrm{n}=5)$ (以下単位と $\mathrm{n}$ 数は同じ), $\mathrm{R}$ が $0.20 \pm 0.01, \mathrm{RF}$ が $0.21 \pm 0.05, F R$ が $0.10 \pm 0.03$ で，いずれも対照の $0.05 \pm 0.06$ と有意差はなかった.

2）７日保存血液

輸血操作前值は $\mathrm{F}$ が $3.08 \pm 0.32 \mu \mathrm{mol} / \mathrm{gHb}(\mathrm{n}=$ $5)$ (以下単位と $\mathrm{n}$ 数は同じ), $\mathrm{R}$ が $3.15 \pm 0.27, \mathrm{RF}$ が $3.18 \pm 0.35, \mathrm{FR}$ が $3.19 \pm 0.31$ で，いずれも対照 の $3.12 \pm 0.37$ と有意差がなかった.

変化量は F が $0.24 \pm 0.03 \mu \mathrm{mol} / \mathrm{gHb} / 8 \mathrm{~h} \quad(\mathrm{n}=5)$ (以下単位と $\mathrm{n}$ 数は同じ), $\mathrm{R}$ が $0.37 \pm 0.01, \mathrm{RF}$ が $0.29 \pm 0.06, F R$ が $0.24 \pm 0.03$ で，いずれも対照の $0.37 \pm 0.12$ と有意差はなかった。

2. MAP 赤血球内 2,3-DPG 濃度（Fig. 2)

1）3 日保存血液

輸血操作前値は $\mathrm{F}$ が $10.0 \pm 1.8 \mu \mathrm{mol} / \mathrm{gHb}(\mathrm{n}=5)$ 

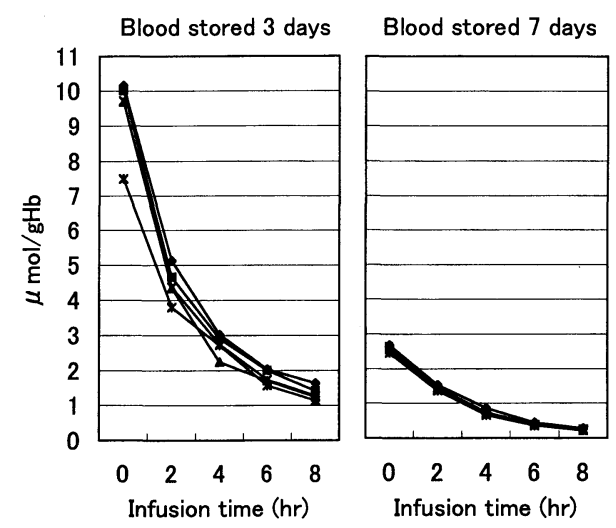

Fig. 2 2,3-DPG activity in infused red cells stored 3 or 7 days. Control, - - ; Filtration, - $-\mathbf{\square}$; Irradiation, - $\mathbf{A}-$; Filtration after Irradiation, $-\times-$; Irradiation after Filtration, - $*$ -

Blood stored 3 days : Value on irradiation after filtration is significantly different $(p<0.05)$ from the control by the t-test before infusion.

(以下単位と $\mathrm{n}$ 数は同じ), $\mathrm{R}$ が $9.7 \pm 2.2, \mathrm{RF}$ が 9.7 $\pm 2.1, \mathrm{FR}$ が $7.5 \pm 1.9$ で, FR(フィルター処理後照 射したもの) が対照の $10.2 \pm 1.9$ より有意に低值で あった。

変化量は $\mathrm{F}$ が $8.6 \pm 1.0 \mu \mathrm{mol} / \mathrm{gHb} / 8 \mathrm{~h}(\mathrm{n}=5)$ （以 下単位と $\mathrm{n}$ 数は同じ), $\mathrm{R}$ が $8.5 \pm 2.0, \mathrm{RF}$ が $8.4 \pm$ 1.3, FR が $6.4 \pm 1.5$ で, いずれも対照の $8.5 \pm 1.1$ と有意差はなかった。

\section{2） 7 日保存血液}

輸血操作前值は $\mathrm{F}$ が $2.6 \pm 1.0 \mu \mathrm{mol} / \mathrm{gHb} \quad(\mathrm{n}=5)$ (以下単位と $\mathrm{n}$ 数は同じ), $\mathrm{R}$ が $2.6 \pm 1.1, \mathrm{RF}$ が 2.5 $\pm 1.0, \mathrm{FR}$ が $2.5 \pm 1.0$ で，いずれも対照の $2.7 \pm 1.1$ と有意差がなかった。

変化量は F が $2.4 \pm 0.7 \mu \mathrm{mol} / \mathrm{gHb} / 8 \mathrm{~h}(\mathrm{n}=5)$ （以 下箪位と $\mathrm{n}$ 数は同じ), $\mathrm{R}$ が $2.4 \pm 0.8, \mathrm{RF}$ が $2.3 \pm$ $0.7, \mathrm{FR}$ が $2.2 \pm 0.7$ で, 対照の $2.4 \pm 0.7$ といずれも 有意差はなかった.

3. MAP 上清遊離へモグロビン濃度（Fig. 3）

1） 3 日保存血液

輸血操作前值は $\mathrm{F}$ が $29.8 \pm 9.1 \mathrm{mg} / \mathrm{d} l,(\mathrm{n}=5)$ (以下単位と $\mathrm{n}$ 数は同じ), $\mathrm{R}$ が $16.3 \pm 3.5, \mathrm{RF}$ が $30.6 \pm 7.7$, FR が $32.7 \pm 8.0$ で, フィルター処理を 行った F, RF, FR が対照の $12.9 \pm 3.9$ より有意に

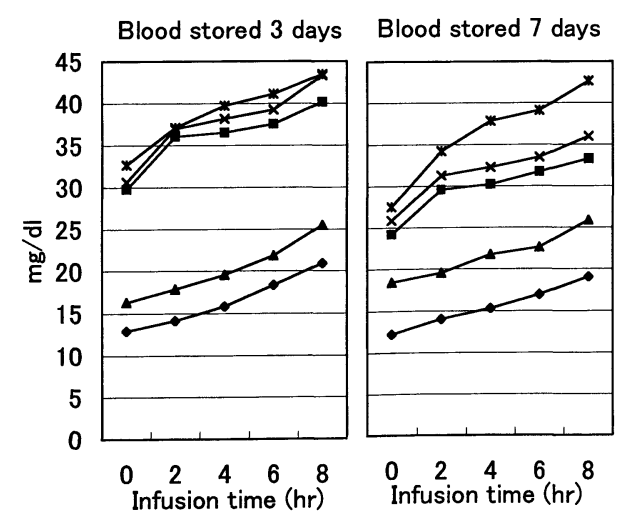

Fig. 3 Concentration of free hemoglobin in the supernatants of infused RC-MAP stored 3 or 7 days. Control, - - ; Filtration, - - ; Irradiation, $-\mathbf{\Delta}-$; Filtration after Irradiation, $-\times-$; Irradiation after Filtration, $-*$ -

Blood stored 3 days : Values for filtration, filtration after irradiation and irradiation after filtration are significantly different $(\mathrm{p}<0.05)$ from the control by the t-test before infusion.

Blood stored 7 days : Values for filtration, irradiation, filtration after irradiation and irradiation after filtration are significantly different $(\mathrm{p}<0.05)$ from the control by the $t$-test before infusion. Irradiation after filtration group is significantly different $(\mathrm{p}<0.05)$ from the control values after infusion.

高値であった.

変化量は $\mathrm{F}$ が $10.3 \pm 5.4 \mathrm{mg} / \mathrm{d} l / 8 \mathrm{~h}(\mathrm{n}=5) （$ 以下 単位と $\mathrm{n}$ 数は同じ), $\mathrm{R}$ が $9.2 \pm 2.8, \mathrm{RF}$ が $12.7 \pm$ 5.8, FR が $10.7 \pm 6.2$ で，いずれも対照の $8.0 \pm 1.2$ と有意差がなかった。

\section{2）７日保存血液}

輸血操作前値は $\mathrm{F}$ が $24.2 \pm 4.6 \mathrm{mg} / \mathrm{d} l(\mathrm{n}=5)$ （以 下単位と $\mathrm{n}$ 数は同じ), $\mathrm{R}$ が $18.4 \pm 2.9, \mathrm{RF}$ が 25.9 $\pm 4.0, \mathrm{FR}$ が $27.5 \pm 4.1$ で，いずれの前処理を行っ た検体も対照の $12.2 \pm 2.3$ より有意に高值であっ た。

変化量は F が $9.1 \pm 3.8 \mathrm{mg} / \mathrm{d} l / 8 \mathrm{~h} \quad(\mathrm{n}=5)$ (以下 単位と $\mathrm{n}$ 数は同じ), $\mathrm{R}$ が $7.5 \pm 1.6, \mathrm{RF}$ が $10.1 \pm$ 2.1, FR が $15.1 \pm 2.7$ で, FR（フィルター処理後照 射）が対照の $6.8 \pm 1.1$ より有意に大きかった。な お, 最高值は FR の 8 時間輸血操作後の $42.6 \mathrm{mg} /$ $\mathrm{d} l$ であった。 


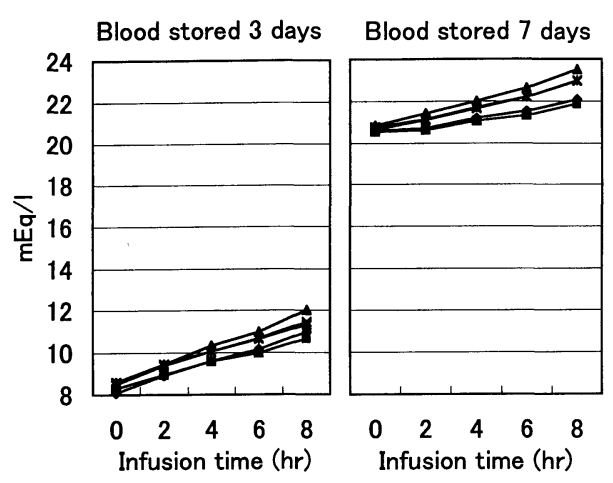

Fig. 4 Concentration of potassium in the supernatants of infused RC-MAP stored 3 or 7 days. Control, - - ; Filtration, - $\mathbf{-}-$; Irradiation, $\boldsymbol{\Delta}-$; Filtration after Irradiation $-\times-$; Irradiation after Filtration, - $*$ -

No significant differences from the control were seen.

4. $\mathrm{MAP}$ 上清 $\mathrm{K}^{+}$濃度（Fig. 4）

1）3 日保存血液

輸血操作前值は $\mathrm{F}$ が $8.3 \pm 1.1 \mathrm{mEq} / \mathrm{l} \quad(\mathrm{n}=5)$ ）(以 下単位と $\mathrm{n}$ 数は同じ), $\mathrm{R}$ が $8.5 \pm 1.1, \mathrm{RF}$ が $8.5 \pm$ 1.1, FR が $8.6 \pm 1.1$ で，いずれも対照の $8.1 \pm 1.2$ と有意差がなかった.

変化量は F が $2.3 \pm 0.0 \mathrm{mEq} / \mathrm{l} / 8 \mathrm{~h} \quad(\mathrm{n}=5)$ （以下 単位と $\mathrm{n}$ 数は同じ), $\mathrm{R}$ が $3.5 \pm 0.0, \mathrm{RF}$ が $3.0 \pm 0.1$, FRが $2.7 \pm 0.1$ で，いずれも対照の $2.9 \pm 0.1$ と有意 差はなかった。

2） 7 日保存血液

輸血操作前值は $\mathrm{F}$ が $20.5 \pm 1.9 \mathrm{mEq} / \mathrm{l}(\mathrm{n}=5)$ （以 下単位と $\mathrm{n}$ 数は同じ), $\mathrm{R}$ が $20.8 \pm 2.0, \mathrm{RF}$ が 20.7 $\pm 2.0, \mathrm{FR}$ が $20.8 \pm 2.0$ で，いずれも対照の $20.7 \pm$ 2.0 と有意差がなかった。

変化量は $\mathrm{F}$ が $1.3 \pm 0.1 \mathrm{mEq} / \mathrm{l} / 8 \mathrm{~h} \quad(\mathrm{n}=5)$ （以下 単位と $\mathrm{n}$ 数は同じ), $\mathrm{R}$ が $2.7 \pm 0.1, \mathrm{RF}$ が $2.3 \pm 0.1$, FR が $2.2 \pm 0.2$ で，いずれも対照の $1.5 \pm 0.1$ と有意 差はなかった。

\section{考察}

低出生体重児への輸血が成人と異なるのは輸注 ポンプを使う, ラインが加温した保育器内を通る, 輸血ラインや穿刺針が細いなどである．現在，頻 用されるシリンジを押す型のポンプは溶血を起こ
す危険は少ないと考えられている．また，加温さ れた保育器内を通過するのに時間がかかり血液に 細菌污染があると輸血中に増殖する危険性はある が, 器内温は輸血用の加温器より低く, 熱で溶血 を起こす危険はないとされている.

針の細さと注入速度について, Macdonald ら は $24 \mathrm{G}$ の針では $0.3 \mathrm{ml} /$ 秒以上で, $22 \mathrm{G}$ の針では $1.5 \mathrm{ml} /$ 秒以上で輸血操作を行なうと溶血が起る と報告している．手でシリンジを押す場合は一時 的に高圧になる可能性がある.しかし, 注入ポン プの速度は今回の検討のように通常 0.0006〜 $0.003 \mathrm{ml} /$ 秒で，針が $24 \mathrm{G}$ であっても溶血を起こ す可能性はないと考えられる．以上のことから， 現在保育器内で行われる輸血は, 感染に注意すれ ば，安全と考えられている.

照射の影響について福森ら すると上清 $\mathrm{K}^{+}$濃度が増加し, Brugnara ら ${ }^{8)}$ はそ の原因を赤血球膜が影響を受けるためとしてい る.また, フィルター処理の影響について清水 $ら^{9)}$ ，小本ら ${ }^{10}$ は第 3 世代の白血球除去フィル ター使用後上清遊離へモグロビン濃度が $20 \mathrm{mg} /$ $\mathrm{d} l$ 前後上昇したと報告している．一方，照射と フィルターを併用した場合について長橋ら ${ }^{11}$ は上 清の $\mathrm{K}^{+}$濃度, $\mathrm{pH}$ ならびに赤血球内 $\mathrm{ATP}$ 濃度は 照射やフィルター処理単独と有意差がなかった が，上清遊離へモグロビン濃度はフィルター処理 の併用により有意に増加したと報告している.大 戸ら ${ }^{12)}$ も清 $\mathrm{K}^{+}$濃度に有意差がなかったと報告 している，いずれも，今回の我々の輸血操作前の 検討と同じ結果であり, 上清遊離へモグロビンは 上昇するものの，問題のない範囲と結論される.

保育器内での輸血操作と照射やフィルター処理 の影響を検討した報告は我々が調べ得た範囲では 見つからなかった。今回の検討では照射とフィル ター処理を併用した血液を保育器内で輸血操作し た前後の赤血球内の ATP と 2,3-DPG の濃度, 上 清 $\mathrm{K}^{+}$濃度の変化量は対照と有意差がなかった. し かし，7 日保存血液にフィルター処理後照射を行 なうと対照より上清遊離へモグロビン濃度の増加 が大きかった．操作手順を逆にするとなぜ差が出 るのかは今回の検討からは結論は得られなかっ 
た. 保存期間が関係するのか否かを含め，今後の 検討が必要である.ただ, 検討した保存期間の RCMAP では, 輸血操作後の上清遊離へモグロビン 濃度の最高值は $42.6 \mathrm{mg} / \mathrm{d} l$ で, この值は後記のよ うに臨床的には問題の起こらない範囲であった.

すなわち, $\mathrm{Ht}$ が $25 \%$, 循環血液量が体重の 8.5 \%と仮定し, RC-MAP (Ht 66\%, 上清遊離へモグ ロビン濃度 $50 \mathrm{mg} / \mathrm{d} l$ ) を急速に輸血した場合の児 の血槳遊離へモグロビン濃度推定值を

血槳遊離へモグロビン濃度 $=(\mathrm{RC}-\mathrm{MAP}$ 上清 の遊離へモグロビン量) $\div$ (血漿量 + RC-MAP 上清量)

の式から推計すると,その結果は体重 $1,000 \mathrm{~g}$ の児 に $15 \mathrm{ml}$ (体重の $1.5 \%$ 量) の輸血で血漿遊離へモ グロビン濃度は $3.7 \mathrm{mg} / \mathrm{d} l$ となる. 出生体重 1〜 $1.5 \mathrm{~kg}$ 児の輸血の必要性が出始める生後 4 週目の haptoglobin は $2 \pm 7 \mathrm{mg} / \mathrm{d} l^{13)}$ で, haptoglobin 1.3 $\mathrm{mg}$ は $1 \mathrm{mg}$ のへモグロビンと結合することから, haptoglobinのみでは処理できない場合もある值 である.しかし，ヘモグロビン尿が見られ始める $25 \mathrm{mg} / \mathrm{d} l^{14)}$ 以下であり, 臨床的には問題にならな い値である。

上清 $\mathrm{K}^{+}$濃度は, 今回の検討では照射とフィル ター処理を併用して輸血操作を行っても対照より 有意に上昇することはなかった。しかし，3日より 7 日保存血液の輸血操作後の $\mathrm{K}^{+}$濃度は約 2 倍高 值であった。血液は保存期間が長くなるにつれ上 清 $\mathrm{K}^{+}$濃度が上昇する。長橋ら ${ }^{3)}$ は 10 日保存後 15 $\mathrm{G}$ 照射しフィルター処理した RC-MAP 上清 $\mathrm{K}^{+}$濃 度は $49.9 \pm 4.1 \mathrm{mEq} / l$ と報告している. 上清 $\mathrm{K}^{+}$濃 度が $50 \mathrm{mEq} / \mathrm{l}$ の RC-MAP (Ht 66\%) を急速輸血 した場合の血漿 $\mathrm{K}^{+}$濃度を循環血液量が体重の 8.5 $\%$, Ht が $25 \%$, 血漿 $\mathrm{K}^{+}$濃度が $4 \mathrm{mEq} / \mathrm{L}$ と仮定し Hall ${ }^{15)} の$

血漿 $\mathrm{K}^{+}$量 $=\left(\right.$輸血前体内 $\mathrm{K}^{+}$量 + 輸血 $\mathrm{K}^{+}$量 $)$

$\div$ (血漿量 +輸血 RC-MAP 上清量)

の式でより推計してみた. 体重 $1,000 \mathrm{~g}$ の児に 15 $\mathrm{m} l(15 \mathrm{ml} / \mathrm{kg})$ 輸血した場合は $7.4 \mathrm{mEq} / l$ となる. この值は Shortland $ら^{16)}$ が体重 $1,500 \mathrm{~g}$ 未満の児 では $60 \%$ が不整脈を来すと報告している 7.5 $\mathrm{mEq} / l$ に相当する. 生後間もない児の $\mathrm{K}^{+}$排泄能
は年長児の約 $1 / 4^{17)}$ と低いが, それでも今回の様な 緩徐な輸血では輸血中も尿に $\mathrm{K}^{+}$が排泄され, 急速 輸液ほど血漿 $\mathrm{K}^{+}$濃度は上昇しないと考えられる。

今回の検討から, 採血後 3〜 7 日の RC-MAP に 使用直前に照射とフィルター処理を併用して保育 器内で輸血操作を行った後も上清 $\mathrm{K}^{+}$濃度が 50 $\mathrm{mEq} / l$ を越す製剤はなく, 低出生体重児に急速輸 血が行われても高 $\mathrm{K}^{+}$血漿を招来する危険性は少 ないと考えられる.

\section{まとめ}

3 日および 7 日保存 RC-MAP に使用直前に放 射線照射とフィルター処理を併用し, 保育器内で 輸血操作を行った場合の安全性を検討した。

7 日保存しフィルター処理後照射したもので上 清遊離へモグロビン濃度が未処理のものより有意 に増加したが, 最高值は $42.6 \mathrm{mg} / \mathrm{d} l$ で臨床的に問 題となる值ではなかった。

上清 $\mathrm{K}^{+}$や赤血球内の ATP と 2,3-DPG の濃度 は照射とフィルター処理を併用して輸血操作を 行っても対照より有意に変化することはなかっ た.

今回の検討から, 細菌污染に注意すれば, 採血 後 3〜 7 日の RC-MAP に使用直前に照射とフィル ター処理を併用して保育器内で低出生体重児に輸 血しても安全と考えられた。

本論文の要旨は, 第 8 回国際輸血学会, 1997 年 3 月, 東 京, で発表した.

謝辞: 試料を御提供頂いた千葉県赤十字血液センター, ならびに御校閲頂いた東邦大学医学部第 1 小児科学講座 月本一郎教授に深謝します.

\section{文献}

1）日本輸血学会輸血後GVHD 対策小委員会: 会告 VII. 輸血によるGVHD 予防のための血液に対す る放射線照射ガイドライン III. 日本輸血学会雑誌 $42: 1-6,1996$.

2) Gilbert, G.L., Hayers, K., Hundson, I.L., James, J., and the Neonatal Cytomegalovirus Infection Study Group : Prevention of transfusion-acquired cytomegalovirus infection in infant by blood filtration to remove leukocytes. Lancet, $1: 1228$, 1989.

3) Bucher, T. : Uber ein phosphatubertragendes garungsferment. Biochem. biophys. Acta (Am- 
st. ), $1: 292-314,1947$.

4) Ericson, A. and de Verdier, C.H. : A modified method for the determination of 2, 3-diphosphoglycerate in erythrocytes. Scand. J. Clin. Lab. Inv., $29: 85-90,1972$.

5) International Committee for Standardization in Haematology : Recommendations for reference method for haemoglobinometry in human blood and specifications for international haemoglobin cyanide reference preparation. J. Clin. Phathol., $31: 139-143,1978$.

6) Macdonald, W. B. and Berg R. B. : Hemolysis of transfused cells during use of the injection (push) technique for blood transfusion. Pediatrics., 23 : 8-11, 1959.

7）福森泰雄, 石見昭子, 田中成憲, 大軒子郎, 柴田 弘俊：X 線照射が RCMAP 中の赤血球に与える 影響. 日本輸血学会雑誌, $39: 979-983,1993$.

8) Brugnara, C. and Churchill, W. H. : Effect of irradiation on red cell cation content and transport. Transfusion, $32: 246-252,1992$.

9) 清水 勝, 藤井寿一, 岡本好雄, 溝口秀昭, 和田 真紀夫, 高本 滋, 比留間潔, 山本恵美, 池田康 夫, 半田 誠, 平野武道: 白血球除去フィルター Z-386 の臨床評価. 新しい医療機器研究, 3：95一 $108,1996$.

10）小本美奈, 粟野文剛, 富永誠一：ベッドサイド白 血球除去フィルターの性能評価, 及び製剤の $\mathrm{pH}$ 值に及ほす影響. 日本輸血学会雑誌, $41 ： 596$ 604, 1995.
11）長橋久方, 森山 哲, 坪倉坌雄, 田所憲治, 中島 一格, 十字猛夫： $\gamma$ 線照射 RC-MAP のフィルター 滤過による影響. 日本輸血学会雑誌, $44: 322$ 327, 1998.

12）大戸 斉，斉野猛司，元木良一，小島健一：白血 球除去フィルターは放射線血の $\mathrm{K}+$ 上昇を起こ さない. 日本輸血学会雑誌, $43: 287,1997$.

13）後藤玄夫：APR-Sc の新生児感染症に対する信憑 性と NICU における臨床応用. 小児科臨床, 41 ： 1709-1717, 1988.

14) Crsby, W.H., Dameshek, W. : The significance of hemoglobinuria and associated hemosiderinuria, with particular reference to various type of hemolytic anemia. J. Lab. Clin. Med., $38: 829-$ 841, 1951.

15) Hall, T.L., Barnes, A., Miller, J.R., Bethencourt, D. M. and Nestor, L. : Neonatal mortality following transfusion of red cells with high plasma potassium levels. Transfusion, $33: 606-609,1993$.

16) Shortland, D., Trounce, J.Q., Levene, M.I. : Hyperkalemia, cardiac arrhythmias, and cerebral lesions in high risk neonates. Arch. Dis. Child., 56 : 1139 - 1143, 1987.

17) Sulyok, E., Nemeth, M., Tenyi, I., Csaba, I.F., Varga, F., Gyory, E., Thurzo, V. : Relationship between maturity, electrolyte balance and the function of the renin-angiotensin-aldosterone system in newborn infants. Biol. Neonat., $35: 60-65$, 1979 . 